\title{
Comparison of Shrinkage, Creep and Elastic Shortening of VMA and Powder Type Self-Compacting Concrete and Normal Vibrated Concrete
}

\author{
Yuvaraj L. Bhirud*, Keshav K. Sangle \\ Structural Engineering Department, Veermata Jijabai Technological Institute, Mumbai, India \\ Email: *yuvarajbhirud@gmail.com
}

How to cite this paper: Bhirud, Y.L. and Sangle, K.K. (2017) Comparison of Shrinkage, Creep and Elastic Shortening of VMA and Powder Type Self-Compacting Concrete and Normal Vibrated Concrete. Open Journal of Civil Engineering, 7, 130-140. https://doi.org/10.4236/ojce.2017.71008

Received: February 6, 2017

Accepted: March 20, 2017

Published: March 23, 2017

Copyright $\odot 2017$ by authors and Scientific Research Publishing Inc. This work is licensed under the Creative Commons Attribution International License (CC BY 4.0).

http://creativecommons.org/licenses/by/4.0/

\begin{abstract}
Self-compacting concrete (SCC) is flowing in nature and hence viscosity modified agent (VMA) or higher amount of binder is used for stability of mix. The mix proportion of SCC is also different from normal vibrated concrete (NC). This modifies the properties of concrete at fresh as well as at hardened state. Three mixes, one VMA type SCC, one powder type SCC and one NC, are considered with identical water to binder ratio. Properties at fresh state such as workability and segregation resistance and at hardened stage such as compressive strength, elastic modulus, shrinkage, creep and elastic shortening are determined and compared. Powder type SCC shows superior properties at fresh stage. Also compressive strength of powder type SCC is found better than that of VMA SCC and NC. Observations show more shrinkage, elastic shortening and creep for powder type SCC as compared with VMA SCC and NC.
\end{abstract}

\section{Keywords}

Self-Compacting Concrete, Elastic Modulus, Shrinkage, Creep, Elastic Shortening, Prestressing

\section{Introduction}

Self-compacting concrete (SCC) can be defined as a concrete which can completely consolidate under its own weight and does not require any external efforts like vibration, floating, poking etc. The mandatory requirements for this concrete are ability of passing, ability of filling and ability of being stable. For getting passing and filling ability of concrete, high range water reducer like superplasticizer is used which goes ahead toward hampering stability of mix. One 
way of achieving stability of mix is providing higher amount of binder material which is classified as powder type and other way is using chemical additives like viscosity modifying agent (VMA) which is classified as VMA type self-compacting concrete. To increase the quantity of binder material, it is added with filler material like fly ash, blast furnace slag, lime stone powder and silica fume [1] [2]. The amount of binder required for stability in VMA type self-compacting concrete is identical as required for normal vibrated concrete. Change in amount of binding material or use of VMA modifies properties of self-compacting concrete from normally vibrated concrete (NC) at fresh as well as at hardened state [3]-[8]. If the concrete is to be used in prestressing work, the properties like shrinkage, creep and elastic shortening are important as these are responsible for losses of prestressing force.

The studies had been carried which give an idea about similarities and changes between various properties of self-compacting concrete and normally vibrated concrete. Bertil Persson et al. [3] and Philippe Turcry et al. [9] have shown that if strength of SCC and NC are similar, then the creep, shrinkage and elastic modulus of SCC were equivalent to those of NC while Jin-Kenn Kim [7] and E. Roziere [10] found that SCC has more shrinkage and creep than NC. Holschemacher [11] also shows that SCC has more shrinkage than NC. Investigations have been carried out for prediction of shrinkage, creep and elastic modulus of SCC using various codes. Jin-Kenn Kim et al. [7] and Stefanus A Kristiawan et al. [12] have shown that ACI 209 R [13] predicts shrinkage of SCC fairly. However B. Barr et al. [14] shows that ACI $209 \mathrm{R}$ model predicts shrinkage fairly for low strength concrete but it creates difference when strength of concrete is more than $45 \mathrm{~N} / \mathrm{mm}^{2}$. Lino Maia et al. [15] shows that Euro Code 2 [16] predicts elastic modulus of concrete fairly. It also shows that creep of SCC can be fairly predicted by Euro Code 2 provided the stress level is kept up to $30 \%$ of strength.

The investigation is undertaken to study properties of two types of self-compacting concrete: VMA type (VMA SCC) and powder type (SCC 550) and normally vibrated concrete $(\mathrm{NC})$ at fresh and hardened state. The mixes with equal binding material content of $400 \mathrm{~kg} / \mathrm{m}^{3}$ for NC and VMA SCC were prepared. One mix of powder type self-compacting concrete with $550 \mathrm{~kg} / \mathrm{m}^{3}$ of binder content has been prepared. Water to binder ratio was kept constant for all mixes. The properties at fresh stage which includes workability, segregation resistance and at hardened stage which includes compressive strength, elastic modulus, shrinkage, creep and elastic shortening were found out and compared. Prediction of shrinkage, creep and elastic modulus is done with ACI 209 R-92 and BS EN 1992-1-1-2004 and compared.

\section{Experimental Program}

At fresh state, the fundamental properties of self-compacting concrete are its filling ability, passing ability and segregation resistance. For workability measurement; slump flow test, V-Funnel test and L-box test were decided to carry out which signify filling ability and passing ability of mix. V-funnel five minutes 
test and visual inspection of slump flow have been used for confirmation of segregation resistance of SCC.

Mix proportion for both powder type and VMA type SCC is opted by using EFNARC guidelines [17] and information and methods available for mix design in various researches is used [18] [19] [20]. A mix with binding material of 550 $\mathrm{kg} / \mathrm{m}^{3}$ is designed with $40 \%$ replacement of binder with fly ash as powder type SCC. After interpreting the results of actual initial trials, suitable changes were made in all the mixes. Mix of VMA type of SCC is prepared with binding material of $400 \mathrm{~kg} / \mathrm{m}^{3}$ and $\mathrm{NC}$ with same binder content. OPC 53 grade cement and fly ash confirming to Class F were used. Crushed basalt stone is used as coarse aggregates. The maximum size of coarse aggregate used is $20 \mathrm{~mm}$ and both 20 $\mathrm{mm}$ and $10 \mathrm{~mm}$ nominal size aggregates were used. Natural river sand is used as fine aggregates. The properties of ingredients used are given in Table 1. The water/binder ratio is kept constant for all three mixes. Polycarboxylate ether based superplasticizer is use to increase workability of mix. The properties are shown in Table 2. The mix proportion used in this study for all three mixes is shown in Table 3.

Table 1. Properties of materials.

\begin{tabular}{cccccc}
\hline \multirow{2}{*}{ Types } & Cement & Fly Ash & Fine aggregates & \multicolumn{2}{c}{ Coarse aggregates } \\
\cline { 5 - 6 } & & & & $10 \mathrm{~mm}$ & $20 \mathrm{~mm}$ \\
\hline Specific Surface area & $325 \mathrm{~m}^{2} / \mathrm{kg}$ & $374 \mathrm{~m}^{2} / \mathrm{kg}$ & - & - & - \\
Specific gravity & 3.15 & 2.3 & 2.79 & 2.9 & 2.9 \\
Fineness Modulus & - & - & 2.93 & 6.09 & 8.11 \\
\hline
\end{tabular}

Table 2. Properties of superplasticizer.

\begin{tabular}{cc}
\hline Appearance & Reddish Coloured liquid \\
\hline $\mathrm{pH}$ & $6-8$ \\
Specific Gravity @ 30 $\mathrm{C}$ & 1.12 \\
Chloride content & $\mathrm{Nil}$ \\
Alkali content & Less than $1.5 \mathrm{~g} \mathrm{Na}_{2} \mathrm{O}$ equivalent/litter \\
\hline
\end{tabular}

Table 3. Mix proportion used for concrete.

\begin{tabular}{ccccc}
\hline & VMA Type SCC & Normal Concrete & Powder Type SCC \\
\hline Cement $(\mathrm{kg})$ & 400 & 400 & 330 \\
Fly Ash (kg) & 0 & 0 & 220 \\
Natural Sand (kg) & 1114 & 688 & 1130 \\
Coarse Aggregates (kg) & $10 \mathrm{~mm}$ & 401 & 412 & 321 \\
Water/binder Ratio & $20 \mathrm{~mm}$ & 172 & 619 & 137 \\
Superplasticizer \% & & 0.33 & 0.33 & 0.33 \\
VMA \% & 1.60 & 0.5 & 1.30 \\
\hline
\end{tabular}


At hardened state, compressive strength, modulus of elasticity, shrinkage, creep and elastic shortening of concrete were determined. To find compressive strength of concrete, cubes of size $150 \mathrm{~mm}$ has been prepared. The compressive strength has been taken at the age of 7, 28 and 56 days. To measure modulus of elasticity of concrete, cylinders of $150 \mathrm{~mm}$ diameter were used. For shrinkage measurement, prismatic specimens of cross section $100 \times 100 \mathrm{~mm}$ were prepared. It is proposed to measure total shrinkage of concrete. All samples prepared for shrinkage measurement are stack vertically and change in length due to shrinkage of sample is measure with the dial gauge of accuracy $0.001 \mathrm{~mm}$ (Figure 1). All the samples are store in the chamber where temperature of $20^{\circ} \mathrm{C}$ $\pm 1^{\circ} \mathrm{C}$ and relative humidity of $50 \%$ is maintained.

Prismatic samples of size $100 \times 100 \times 1200 \mathrm{~mm}$ were casted for pretention prestressing system. High tensile strand cable of $12.5 \mathrm{~mm}$ diameter having tensile strength of $1750 \mathrm{~N} / \mathrm{mm}^{2}$ is used for prestressing work. The cable is placed at the centre of the sample intended for zero eccentricity. This is to ensure continues compressive stress on concrete section after release of prestressing cable. Strain gauge points are affix by adhesive along with lateral sides of the specimen at the position of prestressing reinforcement (Figure 2). All readings for shrinkage and creep are taken up to age of 112 days of concrete.

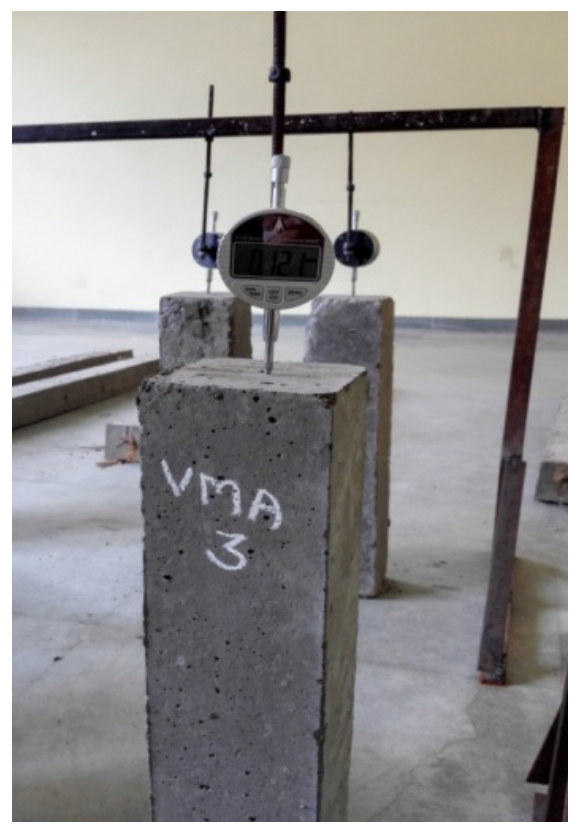

Figure 1. Shrinkage measurement.

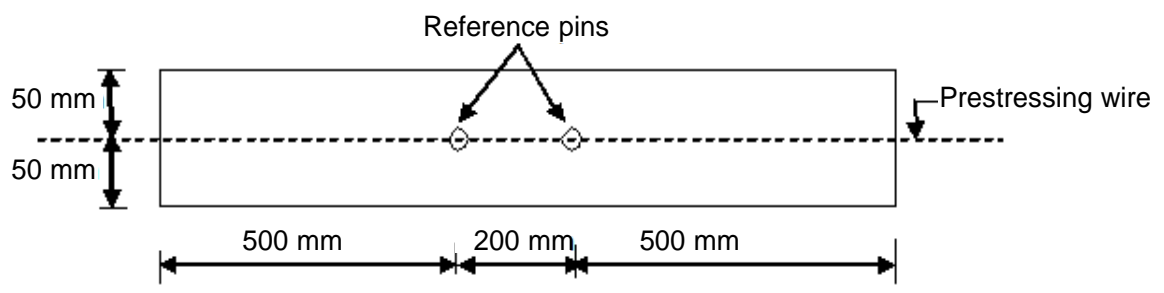

Figure 2. Placement of prestressing wire and reference pins on sample. 


\section{Results and Discussion}

\subsection{Fresh Properties of Concreted}

The results of workability for both SCC are given in Table 4. It is observed that both SCC satisfy all workability conditions decided. V-funnel five minute tests and visual inspection of mix show segregation resistance of the concrete. The spread of coarse aggregates uniformly throughout and till the end of flow in slump flow test is noted which verifies segregation resistance of concrete (Figure 3). For NC, the workability is observed as $79 \mathrm{~mm}$ slump. SCC $550 \mathrm{mix}$ is observed more cohesive and stable in comparison with VMA SCC mix. This is due to virtue of more binder content which imparts stability to mix.

\subsection{Hardened Properties of Concrete}

(a) Compressive strength

Compressive strength of all concrete mixes is shown in Figure 4. It is seen that compressive strength of VMA SCC and NC are identical while SCC $550 \mathrm{mix}$ is having more compressive strength than VMA SCC and NC at all ages. The difference between 28 days and 56 days strength for VAM SCC and NC is minor

Table 4. Results for workability of self-compacting concrete.

\begin{tabular}{cccc}
\hline Test & VMA Type SCC & Powder Type SCC & Permissible Limits \\
\hline Slump Flow diameter $(\mathrm{mm})$ & 690 & 680 & $650-800$ \\
V-Funnel Time $T_{0}(\mathrm{Sec})$ & 11.2 & 8.2 & $6-12$ \\
V-Funnel at $T_{5 \text { minute }}(\mathrm{Sec})$ & 13.8 & 10.9 & $\leq T_{0}+3$ \\
L-Box $T_{20 \mathrm{~cm}}(\mathrm{Sec})$ & 1.2 & 0.89 & $1 \pm 0.5$ \\
L-Box $T_{40 \mathrm{~cm}}(\mathrm{Sec})$ & 2.3 & 2.34 & $2 \pm 0.5$ \\
L-Box Blocking Ratio $\left(H_{2} / H_{1}\right)$ & 0.8 & 0.86 & $0.8-1.0$ \\
\hline
\end{tabular}

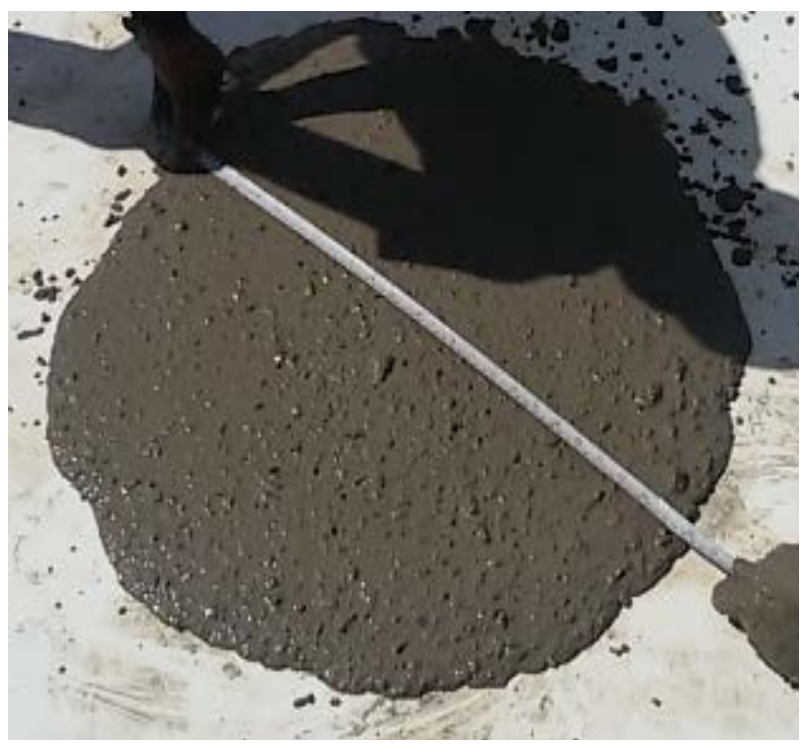

Figure 3. Flow of concrete for slump flow test. 
while it is considerable for SCC 550. This is due to presence of fly ash in SCC $550 \mathrm{mix}$ which has hydration properties but reacts slowly and shows its effect late [21].

\section{(b) Elastic modulus of concrete}

Figure 5 shows elastic modulus of all three mixes and there predicted values using codes ACI 318-89 [22] and BS EN 1992-1-1-2004. It is observed that predictions by code ACI 318-89 are comparable with experimental values obtained. ACI 318-89 code use relation as $4700 \sqrt{f_{c k}}$ for predicting modulus of elasticity of concrete. Table 5 gives values of constant for multiplication with $\sqrt{f_{c k}}$ for obtaining modulus of elasticity and shows that the value is higher for $\mathrm{NC}$ and less for SCC 550. By observation of Table 3, it is seen that amount of course aggregates are more in NC while it is least in SCC 550. The reduction in quantity of coarse aggregates results in decreasing the multiplying constant.

\section{(c) Shrinkage, creep and elastic shortening}

Experimental values obtain for shrinkage strain $\left(\varepsilon_{s}\right)$ of all mixes along with time are shown in Figure 6. It is observed that while shrinkage of NC and VMA SCC are identical, the shrinkage of SCC 550 is seen more. By observing results shown in Figure 7, it is seen that the experimental value for shrinkage of NC is

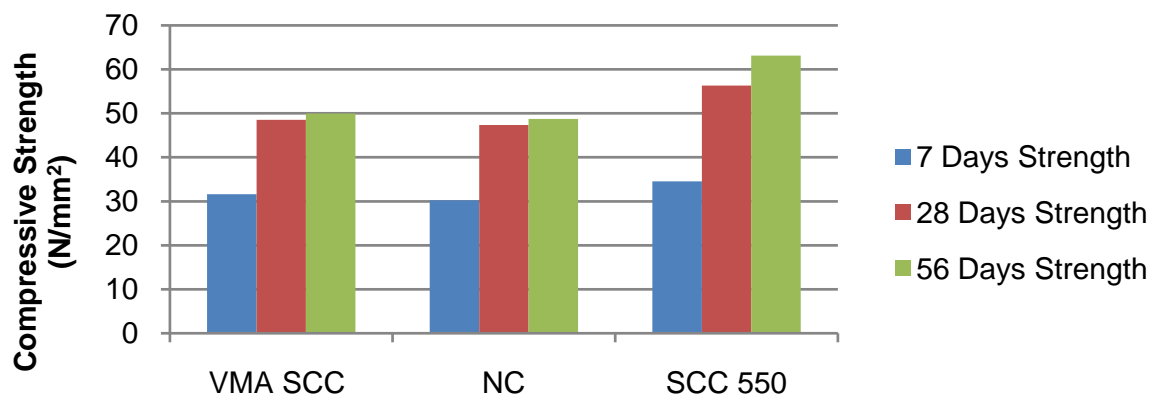

Figure 4. Compressive strength of concrete mixes at various ages.

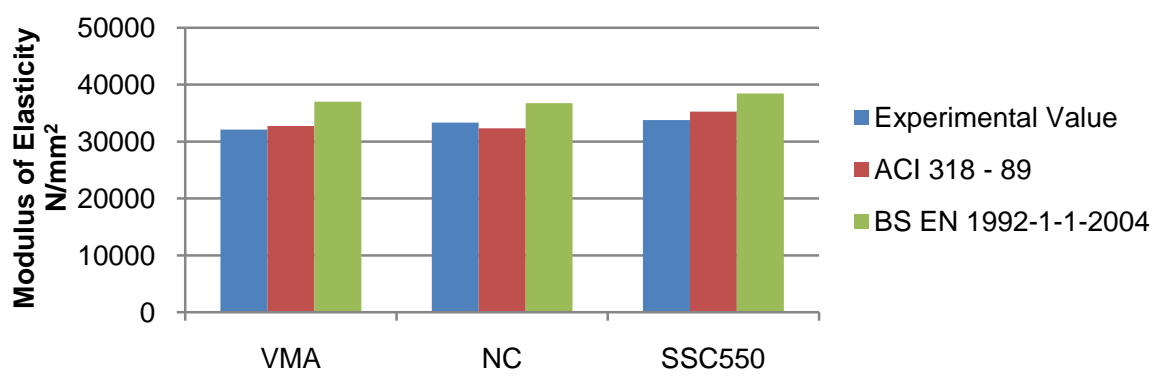

Figure 5. Comparison of experimental and predicted values of elastic modulus.

Table 5. Multiplying factor for $\sqrt{f_{c k}}$.

\begin{tabular}{cc}
\hline Type of Concrete & Value of Multiplying factor for $\sqrt{f_{c k}}$ \\
\hline VMA SCC & 4604 \\
NC & 4844 \\
SSC550 & 4503 \\
\hline
\end{tabular}




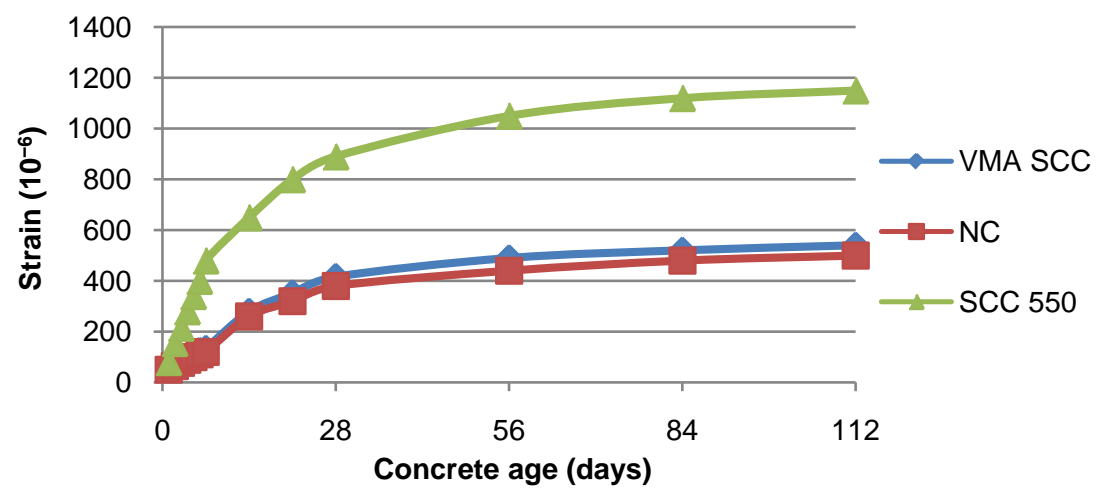

Figure 6. Comparison of shrinkage of all three mixes.

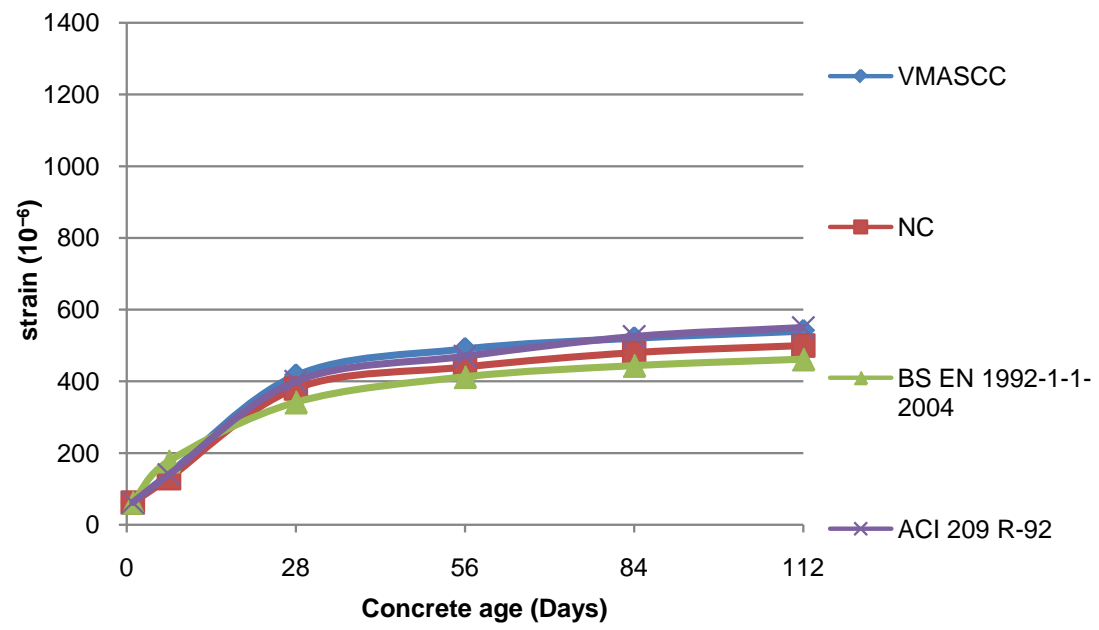

Figure 7. Graph showing comparison of predicted shrinkage and experimental values for VMA SCC and NC.

matching with the predicted values by ACI 209 R- 92 whereas the predicted value of shrinkage by BS EN 1992-1-1-2004 is observed less. The predicted values by ACI 209 R-92 are 5\% more than measured values while predicted values by BS EN 1992-1-1-2004 are 10\% less than measured values for NC. For VMASCC, predicted values by ACI 209 R-92 are closely matching with measured values while BS EN 1992-1-1-2004 underestimates the values by 14\%. In powder type SCC, the estimated values for shrinkage are less than measured values. While ACI 209 R-92 predicted values are 17\% less than measured values, for BS EN 1992-1-1-2004, difference is $54 \%$ for SCC550 concrete (Figure 8). It shows that, while the prediction methods are showing proper prediction for $\mathrm{NC}$ and VMASCC, these are underestimating the shrinkage for powder type SCC.

When prestressing force is transfer to concrete, it undergoes decrease in length because of its elastic properties. Before releasing tendon, again jack was connected to prestressing cable behind anchors. The load was then gradually released on concrete. Strain reading was taken just before and after releasing the tendon. The difference of these reading is noted as elastic shortening $\left(\varepsilon_{e}\right)$. The results are shown in Figure 9 and shows that elastic shortening is more in SCC 550 as compare to VMA SCC and NC. 


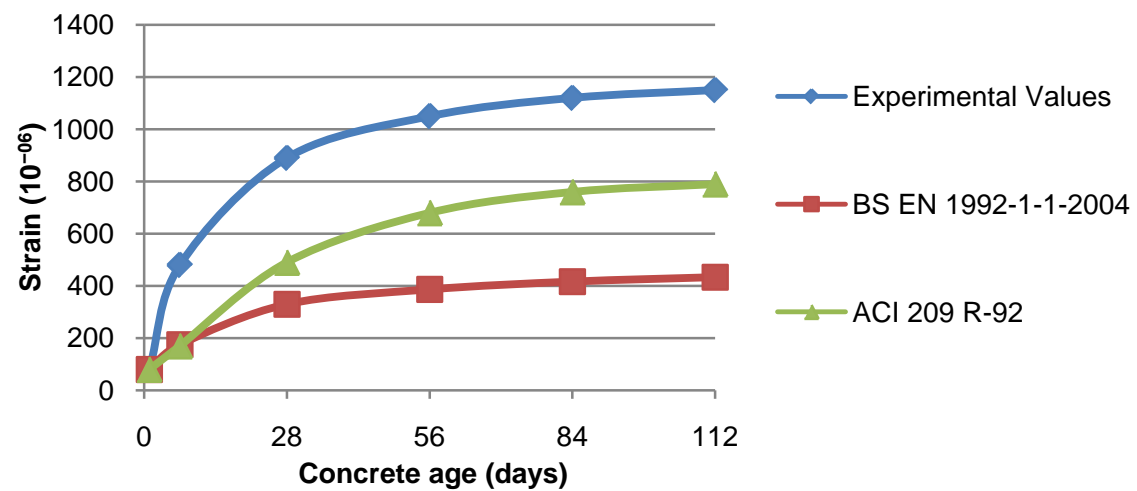

Figure 8. Graph showing comparison of predicted Shrinkage and experimental values for SCC 550 .

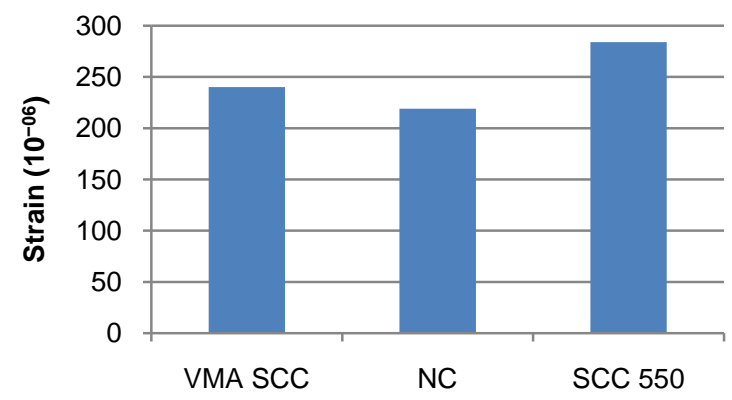

Figure 9. Elastic shortening of all mixes.

After releasing tendon, total strain $\left(\varepsilon_{t}\right)$ is measured with interval of a seven days for first four week and then every twenty eight days till 112 days. The creep strain $\left(\varepsilon_{c}\right)$ is calculated as per Equation (1).

$$
\mathcal{E}_{c}=\varepsilon_{t}-\varepsilon_{s}-\varepsilon_{e}
$$

Figure 10 and Figure 11 are showing experimental and estimated values for creep. By observing Figure 10, it is seen that for NC and VMASCC, predicted values by BS EN 1992-1-1-2004 are less while predicted values by ACI 209 R-92 are more than observed values. The creep predicted by BS EN 1992-1-1-2004 is $16 \%$ less than measured value while it is $38 \%$ more by ACI 209 R- 92 for NC. For VMASCC, the estimated value is less by $21 \%$ for BS EN 1992-1-1-2004 and is $30 \%$ more for ACI 209 R-92 than experimental value. For SCC550, BS EN 1992-1-1-2004 underestimates the Creep wherein ACI 209 R-92 predictions are closely matching with the experimental values (Figure 11).

By observation of Table 6, it is seen that ratio of binding material to concrete for VMA SCC and NC is same whereas it is more in SCC 550; on the contrary, ratio of coarse aggregates to concrete is largest in NC and least in SCC 550. This modifies properties like shrinkage, creep and elastic shortening of concrete. More amount of binding material lead to finer pore structure which in turn gives rise to shrinkage [23] [24]. Less amount of coarse aggregates and higher amount of binder material increases creep and elastic shortening [25]. Because of more coarse aggregates and less binding material in NC in comparison to VMA SCC leads to less shrinkage, creep and elastic shortening and, more binding material 


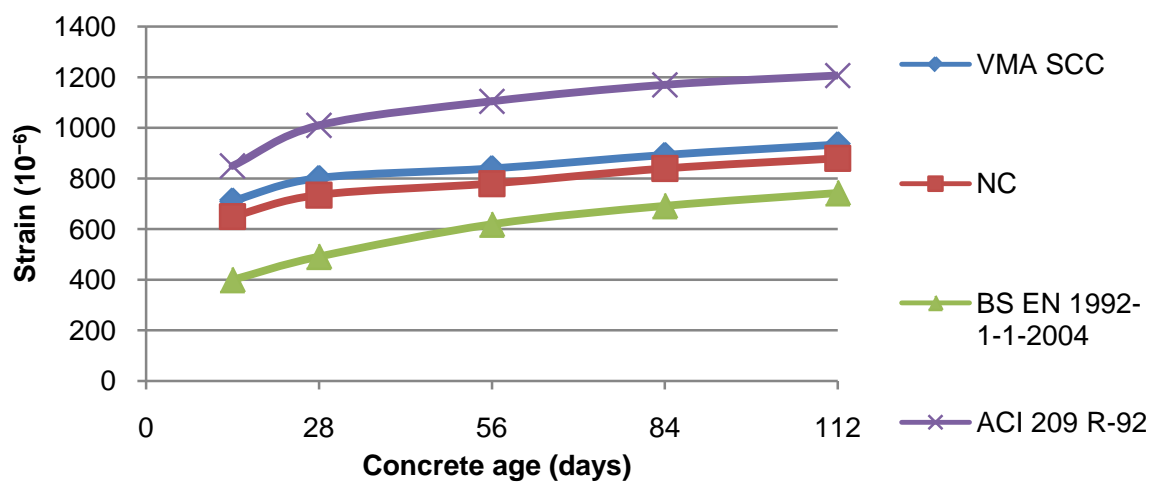

Figure 10. Graph showing comparison of predicted creep and experimental values for VMA SCC and NC.

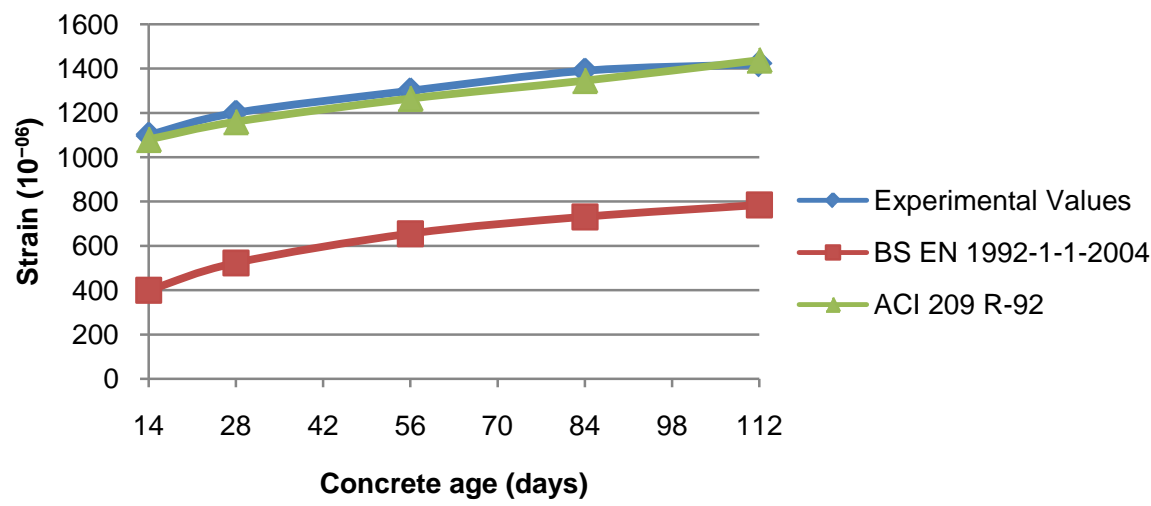

Figure 11. Graph showing comparison of predicted creep and experimental values for SCC 550 .

Table 6. Ratio of binding material and coarse aggregate to concrete.

\begin{tabular}{ccc}
\hline Mix & Ratio of binding material to concrete & Ratio of coarse aggregates to concrete \\
\hline VMA SCC & 0.18 & 0.254 \\
NC & 018 & 0.452 \\
SSC550 & 0.233 & 0.234 \\
\hline
\end{tabular}

and less coarse aggregates in SCC 550 leads to more shrinkage, creep and elastic shortening.

\section{Conclusions}

Three mixes, one normal vibrated concrete, one VMA type Self compacting concrete and one powder type self-compacting concrete, were prepared with identical water/binder ratio. Properties at fresh state such as workability and at hardened stage such as compressive strength, modulus of elasticity, shrinkage, creep and elastic shortening were determined and compared.

- At fresh state, the SCC 550 is found superior as it is more cohesive and stable.

- Compressive strength of SCC 550 is more than that of VMA SCC and NC at 28 days. The rise in strength at 56 days is also more for SCC 550.

- Predictions for elastic modulus of concrete by code ACI 318-89 are compara- 
ble with experimental values obtained. Values of constant for multiplication with $\sqrt{f_{c k}}$ for obtaining modulus of elasticity are more for NC and less for SCC 550 .

- Shrinkage of NC and VMA SCC is observed identical and the shrinkage of SCC 550 is seen more. Observed values for NC and VMASCC are matching with predictions by ACI 209 R-92 whereas shrinkage for powder type SCC observed is more than prediction.

- Elastic shortening is observed more in SCC 550 in comparison to VMA SCC and NC.

- Creep of NC and VMA SCC is identical with a little higher value for VMA SCC while creep for SCC 550 is observed more. Observed creep values are closely matching with ACI 209 R-92 predictions for SCC 550.

- Powder type self-compacting concrete is superior at fresh state and also has more compressive strength but has more shrinkage, elastic shortening and creep as compared with normal vibrated concrete and VMA type self-compacting concrete.

\section{References}

[1] Tarun, R.N., Rakesh, K., Bruce, R. and Fathullah, C. (2012) Development of HighStrength, Economical Self-Consolidating Concrete. Construction and Building Materials, 30, 463-469. https://doi.org/10.1016/j.conbuildmat.2011.12.025

[2] Bertil, P. (2001) A Comparison between Mechanical Properties of Self-Compacting Concrete and Corresponding Properties of Normal Concrete. Cement and Concrete Research, 31, 193-198. https://doi.org/10.1016/S0008-8846(00)00497-X

[3] Deeb, R., Ghanbar, A. and Karihaloo, B.L. (2012) Development of Self-Compacting High and Ultra High Performance Concrete with and without Steel Fibres. Cement and Concrete Composites, 34, 185-190. https://doi.org/10.1016/j.cemconcomp.2011.11.001

[4] Farhad, A. and Shami, N. (2012) Mechanical Properties of Conventional and SelfCompacting Concrete: An Analytical Study. Construction and Building Materials, 36, 330-347. https://doi.org/10.1016/j.conbuildmat.2012.04.034

[5] Mucteba, U. and Kemalettin, Y. (2011) Effect of Mineral Admixtures on Properties of Self-Compacting Concrete. Cement \& Concrete Composites, 33, 771-776. https://doi.org/10.1016/j.cemconcomp.2011.04.005

[6] Aggelos, S.G., Sideris, K.K. and Anagnostopoulos, N.S. (2010) Properties of SCC Produced with Limestone Filler or Viscosity Modifying Admixture. Journal of Materials in Civil Engineering, 22, 352-360. https://doi.org/10.1061/(ASCE)MT.1943-5533.0000030

[7] Jin-Kenn, K., Sang, H.H., Yon, D.P. and Jae, H.N. (1998) Material Properties of SelfFlowing Concrete. Journal of Materials in Civil Engineering, 10, 244-249. https://doi.org/10.1061/(ASCE)0899-1561(1998)10:4(244)

[8] Mehmet, G., Erhan, G. and Erdog, O. (2009) Properties of Self-Compacting Concretes Made with Binary, Ternary, and Quaternary Cementitious Blends of fly Ash, Blast Furnace slag, and Silica Fume. Construction and Building Materials, 23, 1847 1854.https://doi.org/10.1016/j.conbuildmat.2008.09.015

[9] Philippe, T., Ahmed, L., Khalil, H., Gilles, P.C. and Abdeldjelil, B. (2006) Cracking Tendency of Self-Compacting Concrete Subjected to Restrained Shrinkage: Experi- 
mental Study and Modeling. Journal of Materials in Civil Engineering, 18, 46-54. https://doi.org/10.1061/(ASCE)0899-1561(2006)18:1(46)

[10] Roziere, E., Granger, S., Turcry, P. and Loukili, A (2007) Influence of Paste Volume on Shrinkage Cracking and Fracture Properties of Self-Compacting Concrete. Cement and Concrete Composites, 29, 626-636. https://doi.org/10.1016/j.cemconcomp.2007.03.010

[11] Holschemacher, K.H. (2004) Properties of Self Compacting Concrete. Journal of Civil Engineering and Management, 10, 261-266. https://doi.org/10.1080/13923730.2004.9636318

[12] Stefanus, A.K. (2015) Effect of High Volume Fly Ash on Shrinkage of Self Compacting Concrete. Procedia Engineering, 125, 705-712. https://doi.org/10.1016/j.proeng.2015.11.110

[13] ACI 209 R-92 (1997) Prediction of Creep, Shrinkage and Temperature Effect in Concrete Structures. ACI Committee 209.

[14] Barr, B., Hoseinian, S.B. and Beygi, M.A. (2003) Shrinkage of Concrete Stored in Natural Environments. Cement and Concrete Research, 25, 19-29. https://doi.org/10.1016/S0958-9465(01)00044-0

[15] Lino, M. and Joaquim, F. (2012) Early-Age Creep Deformation of a High Strength Self-Compacting Concrete. Construction and Building Materials, 34, 602-612. https://doi.org/10.1016/j.conbuildmat.2012.02.083

[16] BS EN 1992-1-1-2004. Eurocode 2: Design of Concrete Structures-Part 1-1: General Rules and Rules for Buildings.

[17] The European Guidelines for Self Compacting Concrete (2005).

[18] Zhuguo, L., Taka-aki, O. and Yasuo, T. (2004) Flow Performance of High-Fluidity Concrete. Journal of Materials in Civil Engineering, 16, 588-596. https://doi.org/10.1061/(ASCE)0899-1561(2004)16:6(588)

[19] Hassan, E.C. and Adnan, S. (2012) Properties of Self-Consolidating Concrete Made with High Volumes of Supplementary Cementitious Materials. Journal of Materials in Civil Engineering, 25, 1579-1586.

[20] Khaleel, O.R., Al-Mishhadani, S.A. and Razak, H.A. (2011) The Effect of Coarse Aggregate on Fresh and Hardened Properties of Self-Compacting Concrete (SCC). Procedia Engineering, 14, 805-813. https://doi.org/10.1016/j.proeng.2011.07.102

[21] Halit, Y. (2008) The Effect of Silica Fume and High-Volume Class C Fly Ash on Mechanical Properties, Chloride Penetration and Freeze-Thaw Resistance of SelfCompacting Concrete. Construction and Building Materials, 22, 456-462. https://doi.org/10.1016/j.conbuildmat.2007.01.002

[22] ACI 318-89. Building Code Requirements for Reinforced Concrete and Commentary. ACI committee 318, American Concrete Institute, Detroit, Mich.

[23] Valcuende, M., Marco, E. and Serna, P. (2012) Influence of Limestone Filler and Viscosity-Modifying Admixture on the Shrinkage of Self-Compacting Concrete. Construction and Building Materials, 42,583-592.

[24] Jared, C.B., Canh, N.D., Royce, W.F. and Micah, H. (2015) Prestress Losses in Pretensioned Concrete Beams Cast with Lightweight Self-Consolidating Concrete. Structures, 2, 50-57. https://doi.org/10.1016/j.istruc.2015.01.003

[25] Andreas, L., Pietro, L. and Roman, L. (2011) Shrinkage and Creep of SCC-The Influence of Paste Volume and Binder Composition. Construction and Building Materials, 25, 2283-2289. https://doi.org/10.1016/j.conbuildmat.2010.11.019 
Submit or recommend next manuscript to SCIRP and we will provide best service for you:

Accepting pre-submission inquiries through Email, Facebook, LinkedIn, Twitter, etc. A wide selection of journals (inclusive of 9 subjects, more than 200 journals)

Providing 24-hour high-quality service

User-friendly online submission system

Fair and swift peer-review system

Efficient typesetting and proofreading procedure

Display of the result of downloads and visits, as well as the number of cited articles Maximum dissemination of your research work

Submit your manuscript at: http://papersubmission.scirp.org/

Or contact ojce@scirp.org 